\title{
H,K-ATPase type 2 contributes to salt-sensitive hypertension induced by $\mathrm{K}^{+}$restriction
}

\author{
Christine Walter $^{1,2}$ - Mariem Ben Tanfous ${ }^{3}$ - Katia Igoudjil ${ }^{1,2}$ - Amel Salhi ${ }^{1,2}$. \\ Geneviève Escher $^{4} \cdot$ Gilles Crambert ${ }^{1,2}$ (i)
}

Received: 4 March 2016 / Revised: 15 August 2016 / Accepted: 17 August 2016/Published online: 25 August 2016

(C) Springer-Verlag Berlin Heidelberg 2016

\begin{abstract}
In industrialized countries, a large part of the population is daily exposed to low $\mathrm{K}^{+}$intake, a situation correlated with the development of salt-sensitive hypertension. Among many processes, adaptation to $\mathrm{K}^{+}$-restriction involves the stimulation of H,K-ATPase type 2 (HKA2) in the kidney and colon and, in this study, we have investigated whether HKA2 also contributes to the determination of blood pressure (BP). By using wild-type (WT) and HKA2-null mice (HKA2 KO), we showed that after 4 days of $\mathrm{K}^{+}$restriction, WT remain normokalemic and normotensive $(112 \pm 3 \mathrm{mmHg})$ whereas HKA2 KO mice exhibit hypokalemia and hypotension $(104 \pm 2 \mathrm{mmHg})$. The decrease of BP in HKA2 KO is due to the absence of NaCl-cotransporter (NCC) stimulation, leading to renal loss of salt and decreased extracellular volume (by $20 \%$ ). These effects are likely related to the renal resistance to vasopressin observed in HKA2 KO that may be explained, in part by the increased production of prostaglandin E2 (PGE2). In WT, the stimulation of $\mathrm{NCC}$ induced by $\mathrm{K}^{+}$-restriction is responsible for the
\end{abstract}

Gilles Crambert

gilles.crambert@crc.jussieu.fr

1 Sorbonne Universités, UPMC Univ Paris 06, INSERM, Sorbonne Paris Cité, UMR_S 1138, Centre de Recherche des Cordeliers, Université Paris Descartes, F-75006 Paris, France

2 CNRS ERL 8228 - Centre de Recherche des Cordeliers - Laboratoire de Métabolisme et Physiologie Rénale, F-75006 Paris, France

3 Faculté des Sciences de Tunis El Manar, Campus Universitaire 2092, El Manar Tunis, Tunisie

4 Departement für Nephrologie, Hypertonie und klinische Pharmakologie, Universitätsspital Bern - Inselspital, CH-3010 Bern, Switzerland elevation in BP when salt intake increases, an effect blunted in HKA2-null mice. The presence of an activated HKA2 is therefore required to limit the decrease in plasma $\left[\mathrm{K}^{+}\right]$but also contributes to the development of saltsensitive hypertension.

Keywords Blood pressure $\cdot$ Extracellular volume $\cdot$ Low- $\mathrm{K}^{+}$ diet $\cdot$ Vasopressin $\cdot \mathrm{Na}^{+} / \mathrm{Cl}^{-}$-cotransporter

\section{Introduction}

Disturbances in the potassium balance are at the origin of many complications and are potentially life-threatening. The organism is rather well protected against hyperkalemia; however, when it occurs, its consequences (which are mainly cardiac) are rapidly fatal. Hypokalemia is a disorder more frequent than hyperkalemia. The prevalence of hospitalized patients with a plasma $\left[\mathrm{K}^{+}\right]<3 \mathrm{mM}$ is $3-5 \%[29,30]$ and reaches $12 \%$ when the cut-off is $3.5 \mathrm{mM}$ [9]. Its origins are generally multifactorial and involve vomiting, diarrhea, diuretic abuse and can be linked also to genetic disorders (Conn's disease, Bartter and Gitelman syndrome, for instance). In addition to pathological states leading to hypokalemia, dietary behaviors may also contribute to lower the whole body $\mathrm{K}^{+}$content. In developed Western countries, consumption of $\mathrm{Na}^{+}$has increased well above physiological needs whereas that of $\mathrm{K}^{+}$has dramatically decreased [11]. Studies focusing on the impact of a low daily intake of $\mathrm{K}^{+}$in humans have demonstrated a positive correlation with the probability for developing hypertension by mechanisms that remain partly unsettled $[7,14,19]$. Conversely, analysis of $\mathrm{K}^{+}$-depleted animal models (normal or hypertensive) suggests that a low $\mathrm{K}^{+}$intake induces a decrease in blood pressure (BP) $[18,21$, 28]. This discrepancy is probably not related to species 
differences in the blood pressure response to dietary $\mathrm{K}^{+}$restriction but is rather due to the degree of $\mathrm{K}^{+}$restriction, which is moderate in human studies and almost complete in animal studies but also to the large amount of $\mathrm{Na}^{+}$normally ingested by the general population compared to the experimental models. Recent studies $[3,37,39,40]$ highlight the role of the thiazide-sensitive $\mathrm{Na}^{+} / \mathrm{Cl}^{-}$-cotransporter (NCC) in the development of a salt-sensitive hypertension induced by a low$\mathrm{K}^{+}$diet. However, the molecular trigger of NCC stimulation in this context is still debated since it could be hypokalemia [37] or peptide hormones like vasopressin (AVP), for instance [3].

Many coordinated regulatory processes are involved in regulating the potassium balance [42]. In the case of dietary $\mathrm{K}^{+}$ restriction, the retention of $\mathrm{K}^{+}$is favored, via the inhibition of renal $\mathrm{K}^{+}$secretion through the $\mathrm{K}^{+}$channel ROMK (for review see [41]) and the stimulation of $\mathrm{K}^{+}$reabsorption through a progesterone-dependent activation of the H,K-ATPase type 2 (for review see [8]). This last process has been challenged by the lack of renal phenotype in HKA2-null mice fed a low- $\mathrm{K}^{+}$ diet [22]. More recently, however, we have discovered that HKA2-null mice do not retain $\mathrm{K}^{+}$correctly during gestation [34] and exhibit circadian defects in urinary excretion of $\mathrm{K}^{+}$ that affects plasma $\mathrm{K}^{+}$levels [33]. Moreover, when we acutely inhibited the $\mathrm{K}^{+}$-restriction-induced stimulation of HKA2 by blocking the nuclear progesterone receptor, the mice displayed a higher loss of $\mathrm{K}^{+}$in their urine and a lower plasma $\mathrm{K}^{+}$level [12]. These recent data showed that the renal expression of HKA2 is not an epiphenomenon and that HKA2-null mice, as many knock-out models, may develop compensatory systems to override the gene deletion.

Since HKA2 contributes to the regulation of the $\mathrm{K}^{+}$balance and modifications of the dietary $\mathrm{K}^{+}$intake alters BP levels, we aimed at better determining whether HKA2 helps in controlling $\mathrm{BP}$ under $\mathrm{K}^{+}$- depletion conditions.

\section{Material and Methods}

\section{Physiological analysis}

Experiments were performed on C57B16 wild-type (WT) and knock-out mice for the HKA2 $\alpha$ subunit gene [22]. All the animals were house kept at CEF (Centre d'Explorations Fonctionnelles of CRC, Agreement no. A75-06-12). They were maintained in a constant temperature and humidity in light controlled room with a $12 \mathrm{~h}$ light cycle. They had free access to food (SAFE Laboratory) and tap water. All experiments were conducted in accordance with the institutional guidelines and the recommendations for the care and use of laboratory animals put forward by the Directive 2010/63/EU revising Directive 86/609/EEC on the protection of animals used for scientific purposes (project has been approved by a user establishment's ethics committee and the Project
Authorization: number 2289.01). To record physiological parameters, mice were placed in metabolic cages (Techniplast, France) and were fed either a standard laboratory diet $(0.28 \%$ $\mathrm{Na}^{+}$and $0.6 \% \mathrm{~K}^{+}$; Safe France) or a low-K $\mathrm{K}^{+} \operatorname{diet}\left(0.28 \% \mathrm{Na}^{+}\right.$ and $0.01 \% \mathrm{~K}^{+}$; Safe France). Urinary creatinine concentrations were determined using an automatic analyzer (Konelab 20i; Thermo, France). Urinary $\mathrm{Na}^{+}$and $\mathrm{K}^{+}$concentration was determined by flame photometry (IL943, Instruments laboratory, France). Urinary aldosterone content was determined using an EIA kit (USCN Life Science Inc) according to supplier's recommendation. Urine PGE2 was measured by using an EIA method according to supplier's information (Prostaglandin E metabolite EIA kit, Cayman Chemicals). Thiazide and amiloride-sensitive natriuresis were measured as previously described $[20,25]$. To test for the vasopressin response, dDAVP $(1.5 \mu \mathrm{g} / \mathrm{kg}$ in $100 \mu \mathrm{l}$ of $0.9 \% \mathrm{NaCl})$ or its vehicle were injected intraperitoneally and a spot of urine was taken $5 \mathrm{~h}$ post-injection for measurement of osmolality (Vogel 6300 Voebling osmometer, Bioblock Scientific) and compared to the osmolality of urine taken before injections. A specific V2 receptor antagonist (SR121463A, from SanofiAventis, kindly provided by Nadine Bouby, Cordelier Research Center, INSERM [32]) was mixed in the food to provide $1.5 \mathrm{mg} /$ animal. This treatment triggers a comparable polydipsia in WT and HKA2-null mice (40-44 $\mathrm{ml} /$ day in both strain). Plasma volume was determined by Evans blue dye dilution as previously described $[2,6,24]$ in anesthetized animals (a mix of xylazine, $10 \mathrm{mg} / \mathrm{kg}$ and ketamine $100 \mathrm{mg} / \mathrm{kg}$ ). Blood pressure was measured in conscious restrained mice by a tail-cuffed plethysmography method (BP2000, Visitech system, France) after a week of adaptation to the apparatus between 9:00 and 11:00 AM.

\section{Quantitative PCR}

RNAs were extracted from whole kidneys using the TRI reagent (Invitrogen, France) following the manufacturer's instructions. One $\mu \mathrm{g}$ of total RNA was then reversetranscribed (Roche Diagnostics, France) and real-time PCRs were performed on a LightCycler (Roche Diagnostics, France) as previously described [15].

\section{Membrane protein extraction and western blot analysis}

Total kidneys were homogenized in a lysis buffer $(250 \mathrm{mM}$ sucrose, $100 \mathrm{mM}$ Tris-Hepes, $\mathrm{pH} 7.4$ and protease inhibitor cocktail (Complete, Roche Diagnostics)). After removal of aggregates and nuclear-associated membrane by low-speed centrifugations, the plasma membrane enriched fraction $(17,000 \times \mathrm{g}$ for $30 \mathrm{~min})$ was recovered into the lysis buffer and its protein content was measured with the BCA method (Thermo Scientific Pierce). Forty $\mu \mathrm{g}$ of protein were then denaturated, resolved by SDS-PAGE (10\% polyacrylamide) 
and transferred onto a nitrocellulose membrane. Ponceau red labeling was carried out to check for protein loading accuracy. Western blots were performed according to the standard procedure using a polyclonal anti-total NCC antibody, an anti$\mathrm{ENaC} \gamma$ subunit antibody kindly provided by Jan. Loffing (University of Zurich, [36]) or a goat-anti-AQP2 (Santa Cruz). For quantification, the band intensities were normalized by Ponceau red intensity rather than using a protein marker such as $\beta$-actin, the protein expression of which is affected by $\mathrm{K}^{+}$restriction [5].

\section{Immunofluorescence on kidney slice}

Before or after 4 days of $\mathrm{K}^{+}$restriction, anesthetized mice (10 mg/kg xylazine and $100 \mathrm{mg} / \mathrm{kg}$ ketamine) were perfused with $4 \%$ paraformaldehyde in the aorta and the kidneys were removed and frozen in OCT. Five $\mu \mathrm{m}$ thick slices were then processed for immunofluorescence microscopy using an antiAQP2 antibody (1/200) and confocal microscopy analysis (Leica LSM 710).

\section{Data and statistical analysis}

Results are expressed as mean \pm s.e.m. The numbers of mice used in these experiments are indicated in the legends (n). Oneway or two-way ANOVA tests as well as non-paired Student ttest were used to determine statistical significance (see the legends), differences with $p<0.05$ were considered significant.

\section{Results}

\section{Under $\mathrm{K}^{+}$restriction, the absence of $\mathrm{H}, \mathrm{K}$-ATPase type 2 accelerates the development of hypotension}

As already observed $[22,33]$, the dietary $\mathrm{K}^{+}$restriction induced profound physiological changes (Table 1) that differ in their kinetics between WT and HKA2-null mice, including parallel loss of weight and food intake. HKA2-null mice have been shown to loose $\mathrm{K}^{+}$in their feces $[22,33,34]$ thus accelerating the development of hypokalemia that is already present after only 4 days of $\mathrm{K}^{+}$restriction whereas WT mice remained normokalemic (3.16 \pm 0.11 vs $3.60 \pm 0.09 \mathrm{mM}, p=0.005)$.

Systolic BP was measured in wild-type animals under normal $\mathrm{K}^{+}$conditions (NK, white bars) or under dietary $\mathrm{K}^{+}$restriction (LK, gray bars). It remained stable for up to 13 days under normal condition but start decreasing significantly after 13 days of $\mathrm{K}^{+}$restriction ( $p<0.01$ compared to day1 and to day13 of NK; Fig. 1A). Comparison between WT (white bars) and HKA2-null mice under normal dietary conditions (day -1 and day -2) shows no significant differences in their BP level (Fig. 1B). After a switch to a $\mathrm{K}^{+}$restricted diet, the HKA2-null mice decreased their BP (at d1-d2) than in WT mice. The difference in BP between the two genotypes reached 8$15 \mathrm{mmHg}$ up to the 6 th day of $\mathrm{K}^{+}$restriction. After that, the difference disappeared and both genotypes reached a similar, low BP at day 13 (around $100 \mathrm{mmHg}$ ).

\section{Renal $\mathrm{Na}^{+}$and water losses are at the origin of the $\mathrm{K}^{+}$- depletion induced hypovolemia in HKA2-null mice}

We then directly measured plasma volume by injecting a known quantity of Evans blue dye in the circulation. These experiments were carried-out at day 4 of the low- $\mathrm{K}^{+}$diet, when BP has started to decrease in HKA2-null mice but remains normal in WT mice. As shown in Fig. 2A, the volume of the plasma compartment was similar before and after the low-K $\mathrm{K}^{+}$diet switch in WT mice $(934 \pm 57 \mu \mathrm{l}$ and $929 \pm 50 \mu \mathrm{l}$, respectively). In contrast, in HKA2-null mice (Fig. 2B), plasma volume was $200 \mu \mathrm{l}$ lower on the 4 th day of the low- $\mathrm{K}^{+}$diet than before the switch $(837 \pm 49 \mu \mathrm{l}$ and $1044 \pm 67 \mu \mathrm{l}$, respectively; $p=0.027$ ). As expected, WT mice under low- $\mathrm{K}^{+}$diet rapidly decreased their production of aldosterone (by $70 \%$ compared to day-1, $p<0.01$, Fig. 2C). In HKA2-null mice the decrease of urinary aldosterone is more modest and reach only $40 \%$ compared to day-1 $(\mathrm{p}=0.02$ at day 1$)$. Thus, after 4 days of $\mathrm{K}^{+}$restriction, HKA2-null mice excreted 2 times more aldosterone than WT $(p<0.01)$, which may outline that the volume depletion observed in HKA2-null mice "antagonized" the effect of the $\mathrm{K}^{+}$depletion.

A $20 \%$ decrease in plasma volume is likely to originate from a reduced ability of the kidney to retain $\mathrm{Na}^{+}$and water.

Table 1 Metabolic parameters of WT $(n=15)$ and HKA2-null mice $(n=16)$ under normal (day-1) and low K ${ }^{+} \operatorname{diet}($ days 4 and 13$)$. Results are shown as mean \pm s.e.m. HKA2-null mice vs WT, non-paired Student t-test $(* \mathrm{p}<0.05)$

\begin{tabular}{|c|c|c|c|c|c|c|}
\hline \multirow[t]{2}{*}{$\mathrm{K}^{+}$restriction (day) } & \multicolumn{2}{|l|}{ Day -1} & \multicolumn{2}{|l|}{ Day 4} & \multicolumn{2}{|l|}{ Day 13} \\
\hline & WT & HKA2-KO & WT & HKA2-KO & WT & HKA2-KO \\
\hline Weight (g) & $26.0 \pm 1.0$ & $26.3 \pm 0.5$ & $22.0 \pm 1.4$ & $22.6 \pm 0.6$ & $23.3 \pm 0.9$ & $19.0 \pm 0.6^{*}$ \\
\hline Food intake (g) & $4.3 \pm 0.1$ & $4.3 \pm 0.2$ & $3.1 \pm 0.2$ & $2.5 \pm 0.2$ & $3.7 \pm 0.3$ & $2.4 \pm 0.3 *$ \\
\hline Plasma $\mathrm{K}^{+}$value $(\mathrm{mM})$ & $3.95 \pm 0.10$ & $4.12 \pm 0.16$ & $3.60 \pm 0.09$ & $3.16 \pm 0.11 *$ & $3.26 \pm 0.16$ & $2.80 \pm 0.13 *$ \\
\hline Urine $\mathrm{K}^{+} \mu \mathrm{mol} / 24 \mathrm{~h}$ & $515 \pm 32$ & $503 \pm 27$ & $12 \pm 1$ & $10 \pm 4$ & $12 \pm 2$ & $6 \pm 1$ \\
\hline
\end{tabular}



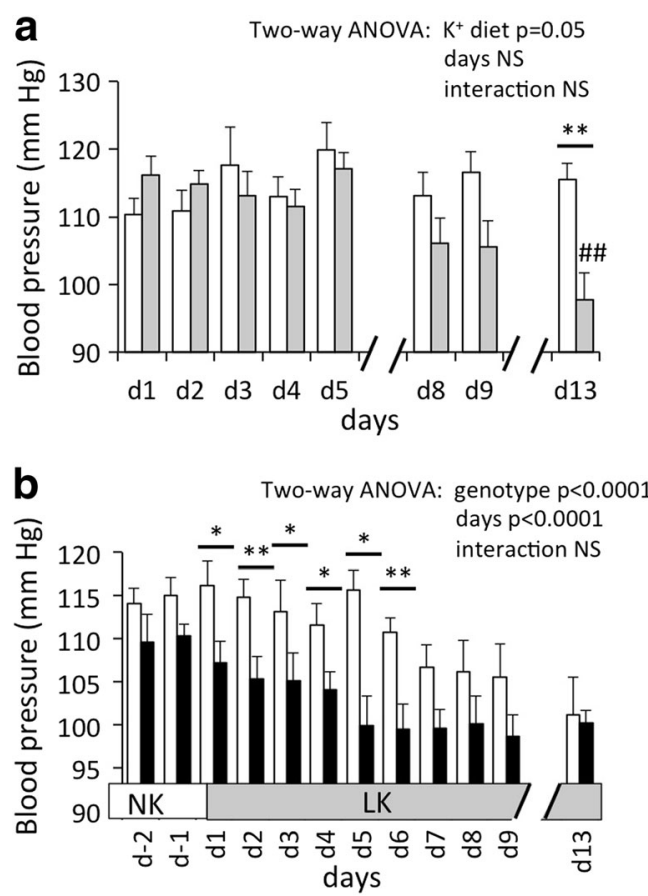

Fig. 1 Effect of dietary $K^{+}$restriction on blood pressure (BP) level. (A) Systolic BP of wild-type (WT) mice under normal (white bars) or low- $\mathrm{K}^{+}$ diet (gray bars). Results are shown as the mean \pm s.e.m. $(n=6-9)$. Twoway ANOVA test was performed to analyze the influence of diet (normal or low- $\mathrm{K}^{+}$diets) and diet duration on blood pressure. (B) Systolic BP in WT (white bars, $n=15-20$ for period d -2 to $\mathrm{d} 4$ and $\mathrm{n}=6-9$ for $\mathrm{d} 5$ to d13) and HKA2-null mice (black bars, $\mathrm{n}=15-20$ for period d-2 to $\mathrm{d} 4$ and $\mathrm{n}=6-8$ for $\mathrm{d} 5$ to $\mathrm{d} 13$ ) before $(\mathrm{d}-2, \mathrm{~d}-1)$ and after a switch to a low- $\mathrm{K}^{+}$diet (d1 to d13). Results are shown as the mean \pm s.e.m. Non-paired Student ttest $(* * p<0.01 ; * p<0.05$ and \#\# $\mathrm{p}<0.01$ compared to d1). Two-way ANOVA test was performed to analyze the influence of genotype and diet duration on $\mathrm{BP}$
We therefore measured urinary water and $\mathrm{Na}^{+}$excretion before and during a four-day period of low- $\mathrm{K}^{+}$diet. As shown in Fig. 2D urine volume was slightly increased (by $30 \%$ at day 4 compared to day-1, $p<0.01$ ) in WT mice under a low- $\mathrm{K}^{+}$diet (white bars) during this period of 4 days and is almost doubled after 13 days of treatment $(\mathrm{p}<0.01)$. In HKA2-null mice, urine volume increased faster than in in WT mice, with an increase of $50 \%$ and $90 \%$ at day 3 and 4 compared to day$1(\mathrm{p}<0.01)$. Therefore, in the short period of $\mathrm{K}^{+}$restriction, the absence of HKA2 induced a higher loss of fluid than in WT mice $(30 \%$ at day $3, p=0.042$ and $50 \%$ at day 4 , $\mathrm{p}<0.01)$. After a prolonged period of $\mathrm{K}+$ restriction, WT and HKA2-null mice displayed a similar loss of fluid. Regarding $\mathrm{Na}^{+}$excretion (Fig. 2E), it was normalized by the amount of food intake so as to avoid biases stemming from the decrease in food intake occurring in both strains after the switch (as discussed above). In WT mice, urinary $\mathrm{Na}^{+}$excretion increased significantly but transiently in the first days after the switch to a $\mathrm{K}^{+}$-restricted diet compared to NK diet $(64 \pm 3 \mu \mathrm{mol} / \mathrm{g}, p<0.01 ; 62 \pm 4 \mu \mathrm{mol} / \mathrm{g}, \mathrm{p}<0.01$ and $59 \pm 4 \mu \mathrm{mol} / \mathrm{g}, p=0.03$ at day 1,2 and 3, respectively; vs. $49 \pm 3 \mu \mathrm{mol} / \mathrm{g}$ under normal conditions) and returned to a normal value at day $4(57 \pm 6 \mu \mathrm{mol} / \mathrm{g}, p=0.165)$ up to day $13(50.8 \pm 5.6 \mu \mathrm{mol} / \mathrm{g}, p=0.83)$. In HKA2-null mice, urinary $\mathrm{Na}^{+}$excretion also increased significantly in response to $\mathrm{K}^{+}$ restriction compared to normal diet $(\mathrm{p}<0.01)$, with a stronger amplitude than that observed in WT mice since these mice lost around $10-20 \mu \mathrm{mol} / \mathrm{g}$ each day during the short period of $\mathrm{K}^{+}$ restriction $(p=0.05$ at day $1, \mathrm{p}=0.03$ at day $2, p=0.02$ at day3 and 4). After a prolonged period of $\mathrm{K}^{+}$restriction, HKA2-null mice returned to a normal value $(45.7 \pm 4.3 \mu \mathrm{mol} / \mathrm{g})$.
Fig. 2 Volume of the plasma compartment and renal water and $\mathrm{Na}^{+}$excretion under low $\mathrm{K}^{+}$diet during $K^{+}$-depletion. Plasma volume of WT $(\mathrm{A}, \mathrm{n}=15)$ and HKA2-null mice $(\mathrm{B}, \mathrm{n}=15)$ in normal conditions (NK) and after 4 days of a low- $\mathrm{K}^{+}$diet (LK). (C) $24 \mathrm{~h}$ urine excretion of aldosterone in WT (white bars, $n=10-12$ ) and HKA2-null mice (black bars, $\mathrm{n}=10-12)$ in normal conditions (day-1) and after a switch to a low$\mathrm{K}^{+}$diet (day1 - day4). Urine volume (D) and $\mathrm{Na}^{+}$content (normalized to food intake, E) from WT ( $\mathrm{n}=10-12$, white bars) and HKA2-null mice $(\mathrm{n}=10-12$, black bars) before (day-1) and after a low- $\mathrm{K}^{+}$diet (day 1-day 13). Results are shown as the mean \pm s.e.m. Non-paired Student t-test $(* * \mathrm{p}<0.01 ; * p<0.05)$ a

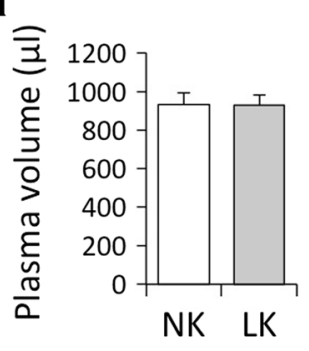

b

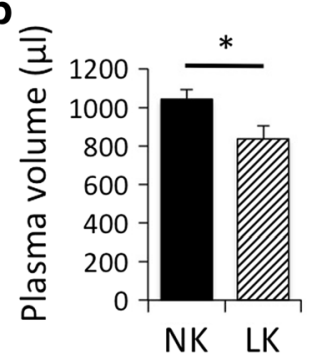

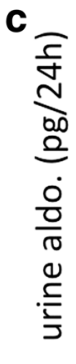

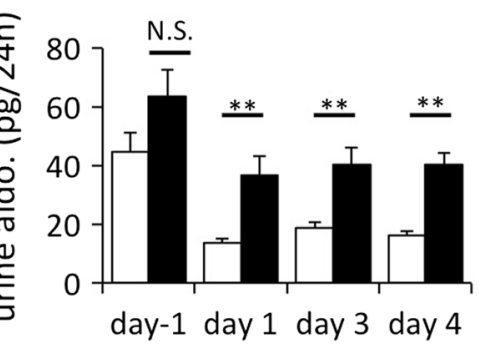

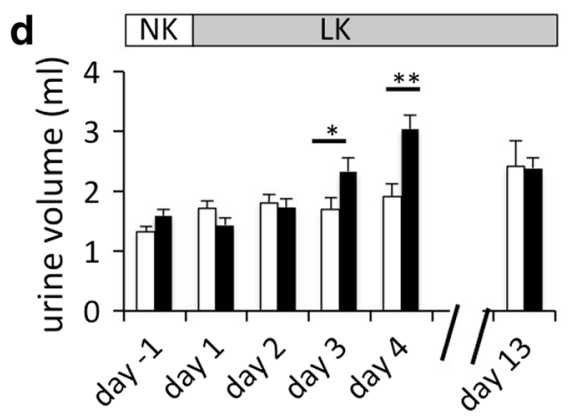

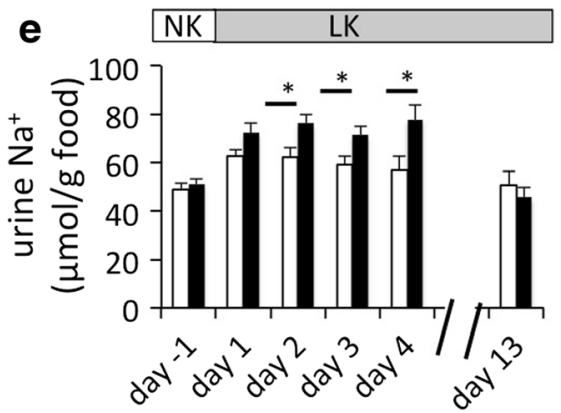




\section{Differential regulation of NCC and ENaC in WT and HKA2-null mice during early $\mathrm{K}^{+}$restriction}

Measurements of total NCC protein expression confirmed that it is increased under the low- $\mathrm{K}^{+}$diet in WT (by $70 \%, p<0.01$ ) but not in HKA2-null animals (Fig. 3A). Finally, the functional activity of NCC was assessed in vivo in both strains before and after a 4-day period of low- $\mathrm{K}^{+}$diet, by measuring the acute natriuretic effect of a single dose of hydrochlorothiazide (ip injection of HCTZ, $50 \mathrm{mg} / \mathrm{kg}$ for $6 \mathrm{~h}$ ). As shown in Fig. 3B, under normal- $\mathrm{K}^{+}$conditions, HCTZ induced a similar natriuretic response in WT and HKA2-null mice (around $100 \mu \mathrm{mol} \mathrm{Na}{ }^{+} / \mu \mathrm{mol}$ of creatinine). During $\mathrm{K}^{+}$restriction, the natriuretic effect of HCTZ was increased by $50 \%$ in WT mice (compared to normal $\mathrm{K}^{+}$condition, $p<0.01$ ). In HKA2null mice, the response to HCTZ $\left(122 \mu \mathrm{mol} \mathrm{Na}{ }^{+} / \mu\right.$ mol creatinine) was not significantly increased compared to that under a normal $\mathrm{K}^{+} \operatorname{diet}(p=0.097)$ and was much weaker than that in WT ( $\mathrm{p}<0.01)$. Thus, NCC stimulation appears to be blunted in HKA2-null mice after 4 days of $\mathrm{K}^{+}$restriction.
The protein expression of the $\gamma$ subunit of $\mathrm{ENaC}(90 \mathrm{kDa}$ band) is decreased by $25 \%$ in WT mice after 4 days of the low- $\mathrm{K}^{+} \operatorname{diet}(\mathrm{p}<0.01)$ and is not modified in HKA2-null mice (Fig. 3C). It has to be noted that a cleaved band at $70 \mathrm{kDa}$ should be observed when ENaC is stimulated. In our Western Blot, this band is barely visible either in normal or low- $\mathrm{K}^{+}$ conditions indicating that $\mathrm{ENaC}$ is not stimulated in any conditions. The functional activity of $\mathrm{ENaC}$ was assessed by testing the natriuretic effect of an acute injection (ip) of amiloride. As shown in Fig. 3D, the natriuretic effect of amiloride was decreased by $30 \%$ in WT mice under the low- $\mathrm{K}^{+}$diet compared to normal conditions $(p=0.03)$. In contrast, the natriuretic response to amiloride in HKA2-null mice was not affected by the change in dietary conditions.

\section{Vasopressin response is blunted in HKA2-null mice at the early stage of $\mathrm{K}^{+}$restriction}

The loss of extracellular volume may also be explained by alteration of the process controlled by vasopressin (AVP).
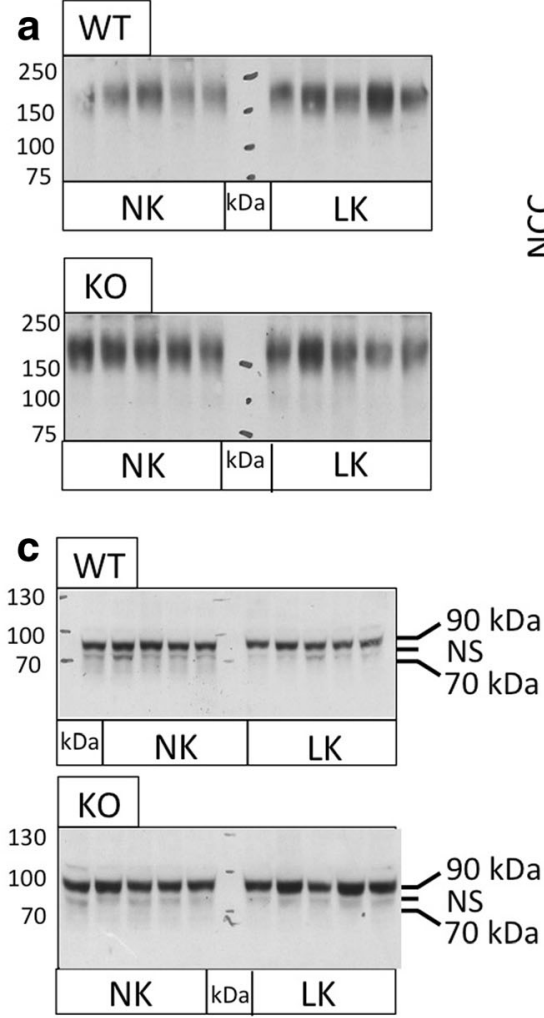

Fig. 3 Regulation of NCC and ENaC in WT and HKA2-null mice under low $-\mathrm{K}^{+}$diet. (A) Protein expression and quantification of NCC on renal membrane preparations from WT and HKA2-null mice (HKA2 KO) under normal (NK) or low- $\mathrm{K}^{+}$diets for 4 days (LK). (B) Natriuretic effects of acute $(6 \mathrm{~h})$ thiazide treatment performed in WT $(n=12)$ and HKA2-null mice $(\mathrm{n}=12)$ before $(\mathrm{NK}$, white bar for WT and black bar for HKA2 KO) and after 4 days of low- $\mathrm{K}^{+}$diets (LK, gray bar for WT and hatched bar for HKA2 KO). This protocol has been shown [20] to not have any natriuretic effect on NCC-null mice indicating that with this b
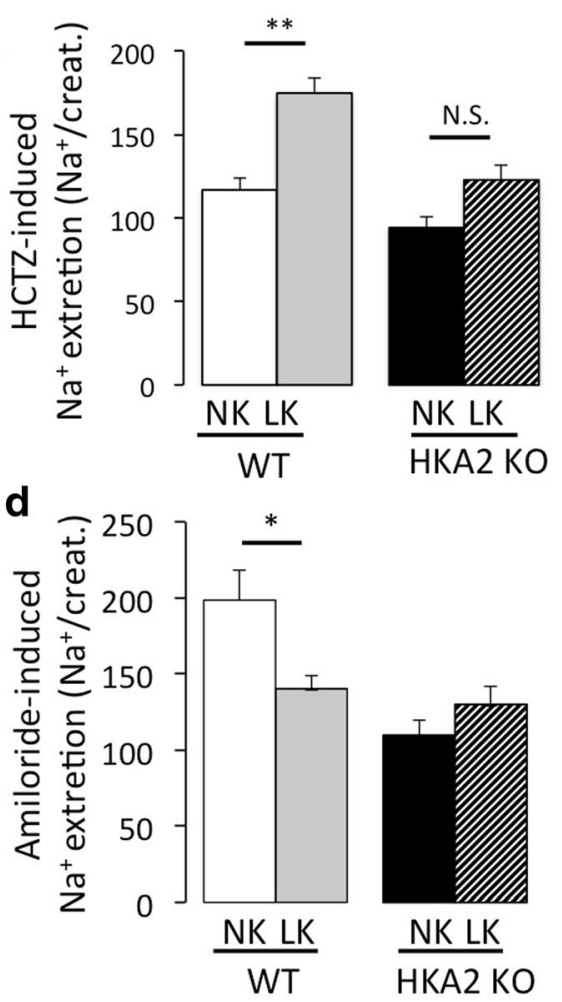

dose and in this time window the only transporter affected is NCC. (C) Protein expression and quantification of $\mathrm{ENaC} \gamma$ subunit on renal membrane preparations from WT and HKA2-null mice (HKA2 KO) under normal (NK) or low- $\mathrm{K}^{+}$diets for 4 days (LK). (D) Natriuretic effects of acute $(4 \mathrm{~h})$ amiloride treatment performed in WT $(\mathrm{n}=12)$ and HKA2-null mice $(\mathrm{n}=12)$ before $(\mathrm{NK}$, white bar for WT and black bar for HKA2 KO) and after 4 days of low- $\mathrm{K}^{+}$diets (LK, gray bar for WT and hatched bar for HKA2 KO). Results are shown as the mean \pm s.e.m. Nonpaired Student t-test $(* * \mathrm{p}<0.01 ; * p<0.05)$ 
We tested this hypothesis by measuring the expression of aquaporin-2 (AQP2) water channels under our different conditions. As shown in Fig. 4A, AQP2 protein (the coreglycosylated form; cg, the fully-glycosylated form; fg or both; total) level is decreased by $30 \%(p<0.05)$ in WT mice after 4 days of $\mathrm{K}^{+}$restriction. In HKA2-null mice (Fig. 4A), $\mathrm{K}^{+}$ restriction induced a more severe decreased (by 55-60 \%) of the expression of AQP2 (cg, fg and total protein, $p<0.01$ ). Noteworthy, under normal condition, although total AQP2 level is similar between WT and HKA2-null mice, the repartition between cg and fg is different. Thus, HKA2-null mice display a higher level of cg AQP2 and a lower level of fg AQP2, possibly indicating that HKA2-null mice have lower level of AQP2 at the cell surface. To better investigate the localization of AQP2, we performed immunolabeling of AQP2 on kidney slices of WT and HKA2-null mice under normal or low $\mathrm{K}^{+}$diet. As shown in Fig. 4B, AQP2 displayed a sharp labeling at the apical sides of collecting duct cells in WT mice fed a normal chow. Potassium restriction slightly modified this localization. In HKA2-null mice under normal diet, the labeling was more diffuse (less sharp) but remained localized to the apical sides indicating that AQP2 may be stored in sub-membrane vesicles. Under low- $\mathrm{K}^{+}$diet (LK), the localization of AQP2 was less pronounced at the apical side and exhibited a strong intracellular labeling in many cells of the HKA2-null mice CD.

To investigate further this hormonal system, we measured the acute concentrating effect of dDAVP (V2 receptor agonist) in WT and HKA2-null mice under normal and low $\mathrm{K}^{+}$diets. As shown in Fig. 4C, in WT animals, 4 days of the low $\mathrm{K}^{+}$diet did not modify urine osmolality compared to the normal diet $(1412 \pm 110$ and $1850 \pm 267 \mathrm{mOsmol} / \mathrm{kg}$, respectively). In both dietary conditions, injection of dDAVP induced a 2fold increase in urine osmolality (Fig. 4C and D), which reached $3151 \pm 199$ and $3166 \pm 118$ mOsmol under the normal and low $\mathrm{K}^{+}$diets, respectively. Therefore, in WT mice under $\mathrm{K}^{+}$restriction, the concentrating effect of dDAVP remains as efficient as in normal conditions. In HKA2-null mice, urine osmolality was similar under the normal and low $\mathrm{K}^{+}$diets $(1994 \pm 228$ and $1895 \pm 204 \mathrm{mOsmol} / \mathrm{kg}$, respectively). As in WT mice, there was a 2-fold increase in urine osmolality after dDAVP injection under normal conditions $(3600 \pm 169 \mathrm{mOsmol} / \mathrm{kg}$, Fig. 4C and D). However, under the low- $\mathrm{K}^{+}$diet, the dDAVP-induced increase in urine osmolality $(2918 \pm 127 \mathrm{mOsmol} / \mathrm{kg})$ was significantly lower than in WT mice (1.5-fold vs 2.3 -fold, $p=0.018$ Fig. 4D). This result
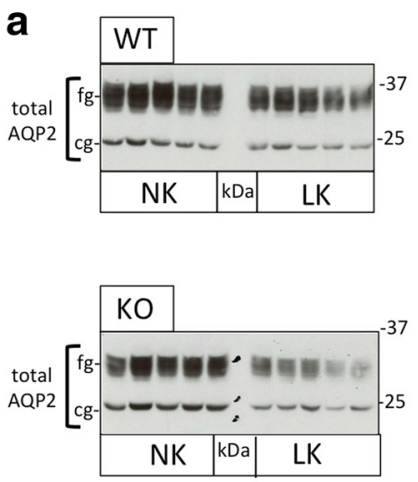

C

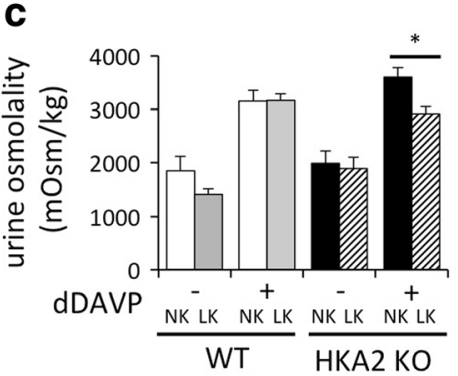

Fig. 4 Modification of the renal water transport system by $K^{+}$restriction. (A) Protein expression of AQP2 in whole kidney of WT (upper panel) and HKA2-null mice (lower panel) and their quantification under normal (NK, white bars for WT and black bars for HKA2-null mice) or low- $\mathrm{K}^{+}$ diets for 4 days (LK, gray bars for WT and hatched bars for HKA2-null mice). Results are shown as the mean \pm s.e.m. $(n=5)$. Non-paired Student t-test $(* * \mathrm{p}<0.01 ; * \mathrm{p}<0.05)$. (B) Cell localization of AQP2 in collecting tubules of WT and HKA2-null mice under normal or low- $\mathrm{K}^{+}$diet. (C) Urine osmolality was measured before and $5 \mathrm{~h}$ after an acute injection of
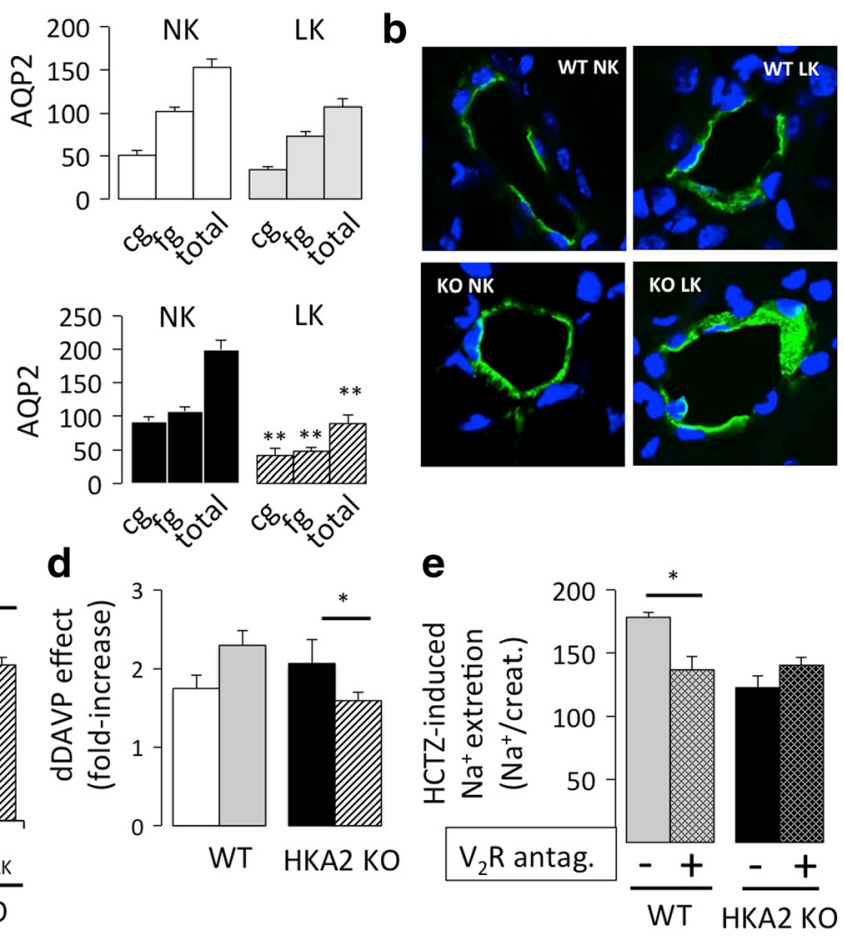

dDAVP to WT mice under normal (white bars) or low- $\mathrm{K}^{+}$diets (gray bars) or to HKA2-null mice under normal (black bars) or low- $\mathrm{K}^{+}$diets (hatched bars). (D) Urine osmolality measured after dDAVP injection normalized by those obtained with the same animal before the treatment. (E) Natriuretic effects of acute $(6 \mathrm{~h})$ thiazide treatment after 4 days of low- $\mathrm{K}^{+}$diets performed in WT ( $n=6$, gray bars) and HKA2null mice ( $\mathrm{n}=6$, black bars) treated (hatched bars) or not (plain bars) by a specific V2 receptor antagonist (SR121463). Results are shown as the mean \pm s.e.m. Non-paired Student t-test $(* p<0.05)$ 
indicates that the response to vasopressin is partially blunted in HKA2-null mice under $\mathrm{K}^{+}$restriction.

To investigate the putative involvement of vasopressin and its $\mathrm{V} 2$ receptors in the stimulation of NCC during a short period of low- $\mathrm{K}^{+}$diet, we treated our mice with a specific V2 antagonist, SR 121463 A. Under NK diet (not shown), this antagonist did not modify the response to thiazide in WT or HKA2-null mice compare to non-treated animals. However, as shown in Fig. 4E, after 4 days of LK diet, the inhibition of $\mathrm{V} 2$ receptors reduced the thiazide-sensitive natriuresis of WT mice but did not affect that of HKA2-null mice. This result indicates that a vasopressin-dependent process targeting the distal convoluted tubules is involved in the natriuretic response to $\mathrm{K}^{+}$-restriction but absent in HKA2-null mice.

\section{HKA2-null mice produce PGE2 in response to $\mathrm{K}^{+}$ restriction}

A possible explanation for both the decreased effect of vasopressin and expression of AQP2 in HKA2-null mice under low- $\mathrm{K}^{+}$diet and their loss of salt may be a higher production of PGE2, a known natriuretic hormone that antagonizes the action of vasopressin $[4,16]$. As shown in Fig. 5A, the mRNA of Cox-2, the enzyme that participates at the generation of PGE2 is increased by almost $50 \%$ in kidney of HKA2-null mice. Moreover, the urinary excretion of PGE2 is 2-fold increased after 4 days of $\mathrm{K}^{+}$restriction in HKA2-null mice but not in WT mice.

\section{HKA2-null mice are protected against salt-sensitive hypertension induced by $\mathrm{K}^{+}$restriction}

The results above demonstrate that WT mice, in the early stage of $\mathrm{K}^{+}$restriction, adapt their renal $\mathrm{Na}^{+}$transport system by stimulating NCC expression and activity. This likely allows the organism to reduce $\mathrm{K}^{+}$secretion in the more distal parts of the nephron by replacing an electrogenic transport system $(\mathrm{ENaC})$ by an electroneutral one $(\mathrm{NCC})$ as previously proposed [13]. Since activation of NCC may robustly enhance $\mathrm{Na}^{+}$reabsorption, we then investigated how $\mathrm{Na}^{+}$excretion and the blood pressure of WT and HKA2-null mice are impacted by an increase in $\mathrm{Na}^{+}$intake after a "preconditioning" period of $\mathrm{K}^{+}$restriction. Table 2 summarizes some physiological parameters showing that addition of $\mathrm{NaCl}$ in the drinking bottle did not modify the differences observed between WT and HKA2-null mice induced by $\mathrm{K}^{+}$restriction such as lower plasma $\left[\mathrm{K}^{+}\right]$and weight in knock-out animals compared to WT. However, both strains exhibited similar urine volume and urine $\mathrm{K}^{+}$excretion. As shown in Fig. 6A, WT and HKA2-null mice exhibit a similar $\mathrm{Na}^{+}$intake after two days of low- $\mathrm{K}^{+}$preconditioning and $\mathrm{Na}^{+}$loading. Renal $\mathrm{Na}^{+}$excretion is increased following $\mathrm{Na}^{+}$loading in both genotype but it tends to increase even more in HKA2-null mice (Fig. 6B), which may suggest a more efficient $\mathrm{Na}^{+}$excretion. To confirm this hypothesis, we normalized the excretion by calculating the mean ratio of the renal excreted $\mathrm{Na}^{+} / \mathrm{Na}^{+}$intake (Fig. 6C) and we observed that WT mice exhibit a lower efficiency to eliminate $\mathrm{Na}^{+}$than HKA2-null mice $(70 \pm 4 \%$ vs $83 \pm 4 \%, p=0.047$ at day 4 ) indicating that HKA2-null mice are more prone to excrete $\mathrm{Na}^{+}$than WT mice when preconditioned by a period low- $\mathrm{K}^{+}$diet. We then measured the consequence of this difference in ability to excrete $\mathrm{Na}^{+}$on the blood pressure level. After two days of $\mathrm{K}^{+}$restriction, addition of $\mathrm{NaCl}$ in the drinking water $\left(\mathrm{K}^{+}\right.$restriction being maintained), significantly raised (one-way ANOVA, $p=0.006$ ) $\mathrm{BP}$, by roughly $15 \mathrm{mmHg}$ (Fig. 6D, black circles, $141 \pm 4$ and $137 \pm 3 \mathrm{mmHg}$, respectively) compared to day 1 and 2 (no salt supplementation, $126 \pm 4 \mathrm{mmHg}$ and $128 \pm 3 \mathrm{mmHg}$ ). In other words, at the early stage of $\mathrm{K}^{+}$

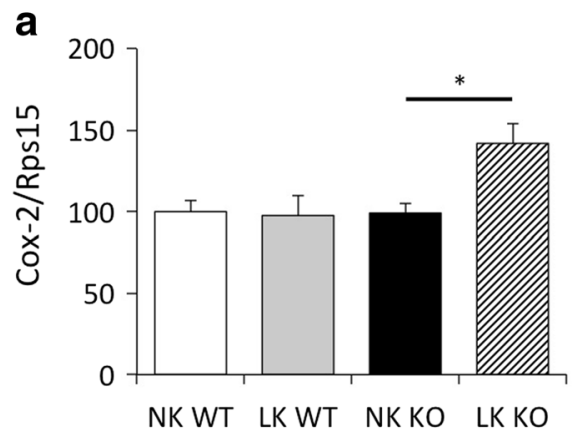

Fig. 5 Urine PGE2 content in WT and HKA2-null mice during $K^{+}$ restriction. (A) mRNA expression of the cyclo-oxygenase isoform 2 (Cox-2) (as a percentage of the mean value obtained either for the WT mice under NK or the HKA2-null mice under NK) normalized to that of rps15, in total kidney of WT mice under a normal diet (NK, white bar, $n=9$ ) or $\mathrm{K}^{+}$restriction (LK, gray bar, $n=12$ ) and of HKA2-null mice under a normal diet (NK, black bars, $n=8$ ) or a low- $\mathrm{K}^{+}$diet for 4 days

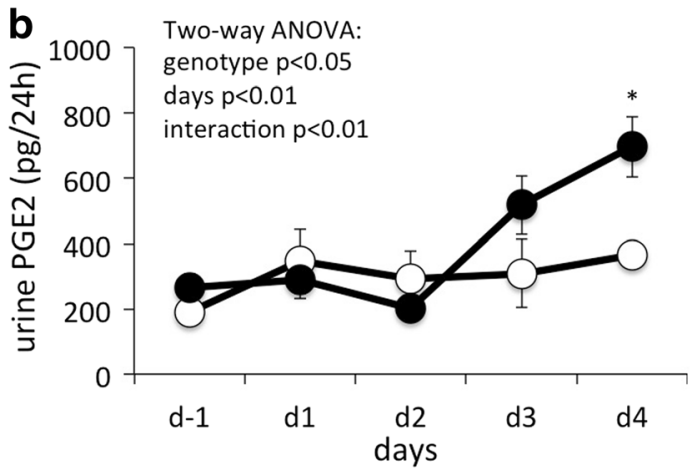

(LK, hatched bars, $\mathrm{n}=9$ ). (B) Total urine PGE2 excretion in WT (white dots) and HKA2-null mice (black dots) before (d-1) and after dietary $\mathrm{K}^{+}$ restriction ( $\mathrm{d} 1$ to $\mathrm{d} 4)$. Results are shown as mean \pm s.e.m. $(n=6)$ Statistical analysis was performed by a two-way ANOVA test to measure the potential effects of genotype, time of diet and their interaction followed by Bonferroni posttests to compare for each time point the WT and HKA2-null mice groups $(* p<0.05)$ 
Table 2 Metabolic parameters of WT and HKA2-null mice under normal diet $(\mathrm{NK} ; \mathrm{n}=15$ and 16 , respectively) and after 2 days under $\mathrm{LK}$ diet and $\mathrm{NaCl}$ loading ( $2 \%$ in drinking water) following a period of 2 days under low $\mathrm{K}^{+}$ diet only $(n=6)$. Results are shown as mean \pm s.e.m. HKA2null mice vs WT, non-paired Student t-test $(* \mathrm{p}<0.05)$

\begin{tabular}{lccccc}
\hline & NK & & \multicolumn{2}{l}{ LK-HNa (day 4) } \\
\cline { 2 - 3 } \cline { 5 - 6 } & WT & HKA2-KO & & WT & HKA2-KO \\
\hline Weight $(\mathrm{g})$ & $28.0 \pm 0.8$ & $27.0 \pm 0.7$ & & $25.7 \pm 0.7$ & $23.4 \pm 0.8^{*}$ \\
Food intake $(\mathrm{g})$ & $3.1 \pm 0.2$ & $3.4 \pm 0.3$ & & $2.5 \pm 0.2$ & $2.0 \pm 0.3$ \\
Plasma $\mathrm{K}^{+}$value $(\mathrm{mM})$ & $4.0 \pm 0.10$ & $4.1 \pm 0.2$ & & $3.4 \pm 0.1$ & $3.0 \pm 0.1^{*}$ \\
Urine volume $(\mathrm{ml})$ & $0.8 \pm 0.1$ & $1.1 \pm 0.2$ & & $12.6 \pm 2.4$ & $13.0 \pm 2.9$ \\
Urine $\mathrm{K}^{+} \mu \mathrm{mol} / 24 \mathrm{~h}$ & $515 \pm 32$ & $503 \pm 27$ & & $12 \pm 1$ & $10 \pm 4$ \\
\hline
\end{tabular}

restriction, when plasma $\left[\mathrm{K}^{+}\right]$levels were not yet affected, WT mice developed a salt-sensitive hypertension. Interestingly, the same protocol conducted in HKA2-null mice did not yield the same results. As shown previously, we observed a decrease in the BP during the first days of $\mathrm{K}^{+}$-restriction (Fig. 6D, day 1 and 2). This decrease was not significantly altered by addition of $\mathrm{NaCl}$ in the drinking water (Fig. 6D, one-way ANOVA, $p=0,07)$ at day $3(113 \pm 3 \mathrm{mmHg})$ and day $4(112 \pm 3 \mathrm{mmHg})$ of the $\mathrm{K}^{+}$restriction period, compared to day 1 and 2 (no salt supplementation, $110 \pm 3 \mathrm{mmHg}$ and $108 \pm 2 \mathrm{mmHg}$ ) or compared to the normal dietary situation (day-1, $117 \pm 2 \mathrm{mmHg}$ ).
Finally, comparison of WT (Fig. 6D, circles) and HKA2null mice (Fig. 6D, squares) clearly demonstrates that the absence of HKA2 protects against the development of this saltsensitive hypertension. Indeed, the difference in BP between both strains is not significant under normal conditions (day-1), increases as previously shown (Fig. 1B) during the first days of $\mathrm{K}^{+}$depletion, and finally reaches almost $30 \mathrm{mmHg}$ when salt supplementation is provided during $\mathrm{K}^{+}$restriction (day 3 and 4 , black circles and squares). Statistical analysis by a twoway ANOVA test showed that the BP depends on genotypes $(p<0.0001)$, the type of diets $(p<0.01)$, and the interaction of both factors $(p=0.03)$.
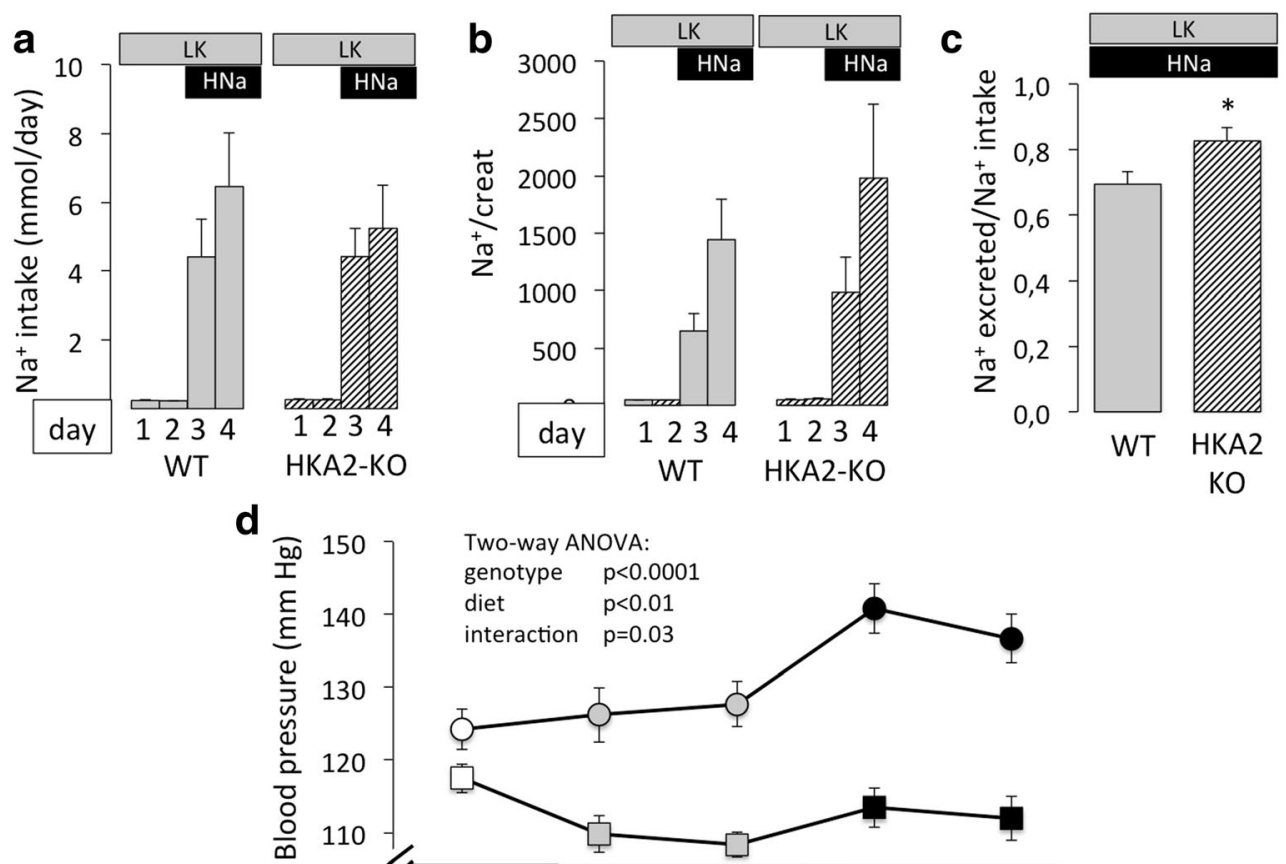

Two-way ANOVA:

genotype $\quad p<0.0001$

diet $\quad p<0.01$

interaction $p=0.03$
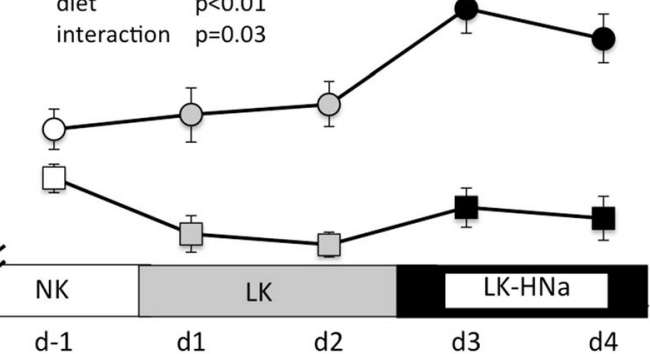

Fig. 6 Effect of increased $\mathrm{Na}^{+}$intake during $\mathrm{K}^{+}$restriction on blood pressure level of WT and HKA2-null mice. (A) $\mathrm{Na}^{+}$intake of WT and HKA2 $\mathrm{KO}$ mice under low- $\mathrm{K}^{+}$diet and challenged with a load of $\mathrm{NaCl}$ $(\mathrm{n}=6)$. (B) Urine $\mathrm{Na}^{+} /$creatinine excretion of WT and HKA2 KO mice under low- $\mathrm{K}^{+}$diet and challenged with a load of $\mathrm{NaCl}(\mathrm{n}=6)$. (C) Calculation of the $\mathrm{Na}^{+}$excretion efficiency ( $\mu \mathrm{mol}$ excreted $/ \mu \mathrm{mol}$ ingested) the fourth day of the experiment. (D) Systolic BP was

measured in WT (circles) and HKA2-null (squares) mice submitted to a normal diet (white symbols), a low- $\mathrm{K}^{+} \operatorname{diet}$ (gray symbols) and a low- $\mathrm{K}^{+} /$ high $\mathrm{Na}^{+}$diet (black symbols). Results are shown as the mean \pm s.e.m. $(\mathrm{n}=12-15)$. Statistical analysis was performed by a one-way ANOVA test for a given genotype and by a two-way ANOVA test to measure the potential effects of genotype and diet 


\section{Discussion}

In animal models, the induction of hypotension by a complete $\mathrm{K}^{+}$restriction has been described in many studies using different animal species [18, 21, 28], however, in humans for reasons discussed below reduction of $\mathrm{K}^{+}$intake is generally related to hypertension. In the present study, we tried to understand the mechanisms linking $\mathrm{K}^{+}$balance and the control of the BP. Interestingly, we show in this study that the absence of the HKA2 affects the regulation of volemia and BP during $\mathrm{K}^{+}$restriction. This could be, in part, linked to unspecific effects related to a lower body weight or to general physiological alterations induced by the depletion of $\mathrm{K}^{+}$. However, we rather propose that the reduction of blood volume and, consequently, of blood pressure is a physiological response that helps maintaining the plasma $\mathrm{K}^{+}$level in the HKA2-null mice as we will discuss below.

\section{Short-term adaptation to $\mathrm{K}^{+}$restriction requires modification of the renal $\mathrm{Na}^{+}$transport system in wild-type animals}

It is well established that a low- $\mathrm{K}^{+}$diet induces a fall in aldosterone production that results in a decrease in $\mathrm{ENaC}$ expression [13] and in vivo activity (this study). In addition, the decreased $\mathrm{Na}^{+}$transport in the thick ascending limb of $\mathrm{K}^{+}$depleted animal reported years ago [17] was associated by Amlal et al. [1] to the reduced mRNA expression as well as the low activity of $\mathrm{NKCC} 2$. $\mathrm{ENaC}$ and $\mathrm{NKCC} 2$ inhibition should lead to a major loss of $\mathrm{Na}^{+}$and fluid in the urine. However, $\mathrm{K}^{+}$-depleted WT animals only slightly increase their urinary volume and $\mathrm{Na}^{+}$excretion and therefore seem to compensate these diuretic and natriuretic effects. Here, we showed that this compensation involves an increase in the expression and activity of NCC and requires the preservation of an efficient vasopressin system. The stimulation of total NCC expression during a low- $\mathrm{K}^{+}$diet has been reported by Palmer's group in rats [13] but not by Nguyen et al. [28]. Recently, Castenada-Bueno et al. [3] as well as Wade et al. [40] observed, in WT mice under the same dietary conditions as ours (4 days of a low- $\mathrm{K}^{+}$diet), a similar increase in total $\mathrm{NCC}$ protein expression. We did not determine the level of $\mathrm{pNCC}$ but the natriuretic effect of thiazide (with a protocol targeting specifically NCC and not the pendrin/NDCBE electroneutral transporters [20]) was clearly more important in WT mice under a low- $\mathrm{K}^{+}$diet, which indicates indeed increased activity of this transporter. It is therefore likely that the stimulation of $\mathrm{NCC}$ activity during a low- $\mathrm{K}^{+}$diet helps to compensate for the decrease in $\mathrm{NKCC} 2$ and $\mathrm{ENaC}$ expression/activity. Interestingly, Morris et al. [26] reported that the absence of NCC provokes a higher loss of fluid during $\mathrm{K}^{+}$restriction, underlying the importance of this transporter to maintain extracellular volume levels in this given condition. More recently, Tecker et al. [37]. confirmed the role of NCC activation during $\mathrm{K}^{+}$restriction and demonstrated that NCC-null mice do not develop hypertension in this context.

\section{Is vasopressin the key hormone to preserve extracellular volume during a low- $\mathrm{K}^{+}$diet?}

Interestingly, in their study, Castaneda-Bueno et al. showed that $\mathrm{NCC}$ activation under $\mathrm{K}^{+}$restriction (WNK4-independent) is different than that mediated by angiotensin II infusion (WNK4-dependent). Since OSR1 (which may compensate for the absence of SPAK under a low- $\mathrm{K}^{+}$diet) is phosphorylated after a vasopressin infusion [31, 35], this hormone may be the trigger for promoting water preservation and stimulation of NCC. To support this hypothesis, we showed, in the present study, that in the context of $\mathrm{K}^{+}$restriction, the inhibition of the vasopressin pathway depending on V2 receptors impedes the stimulation of NCC. Conversely, in HKA2-null mice under $\mathrm{K}^{+}$ restriction, we showed that vasopressin was less efficient in elevating urine osmolality and that $\mathrm{AQP} 2$ protein level was more severely decreased than in WT and that V2 receptor antagonism has no effect on NCC activity. All these results indicate that the vasopressin system is blunted in these animals after 4 days of a low- $\mathrm{K}^{+}$diet. Interestingly, in this context, the plasma $\left[\mathrm{K}^{+}\right]$of HKA2-null mice is $20 \%$ lower than in wild-type animals (Table 1), leading to a clear hypokalemia and modification of this parameter may interfer with vasopressin production. Some reports suggest that an increase in $\mathrm{K}^{+}$intake [10] or in plasma $\left[\mathrm{K}^{+}\right][38]$ could stimulate the production or release of vasopressin. Conversely, $\mathrm{K}^{+}$-depleted rats displaying hypokalemia exhibit a blunted response to vasopressin injections [27]. These results indicate a relationship between the level of plasma $\left[\mathrm{K}^{+}\right]$and vasopressin action. Therefore, the marked hypokalemia occurring in HKA2-null mice after a short period of $\mathrm{K}^{+}$ restriction may explain the reduced effects of vasopressin. A mechanistic reason for the blunted response to vasopressin remains to be investigated in more detail, but we propose that the increased production of PGE2, a factor that antagonizes vasopressin effects in different segments $[4,16]$, is a possible explanation.

\section{Low $\mathrm{K}^{+}$diet and salt-sensitive hypertension}

A recent report suggests that a decrease of plasma $\left[\mathrm{K}^{+}\right]$could trigger the decrease of intracellular $\left[\mathrm{Cl}^{-}\right]$and in fine result in activation of NCC through WNK4 [37]. Our physiological observations do not fully support this idea. Indeed, a decrease in $\mathrm{K}^{+}$intake that does not affect plasma $\left[\mathrm{K}^{+}\right]$(our WT mice after 4 days of LK diet as well as in [3]) already activates NCC and induces a salt-sensitive hypertension. It seems therefore not necessary to reach a state of hypokalemia to activate thiazide-sensitive $\mathrm{Na}^{+}$transport in the DCT. We, also, described a situation where the development of hypokalemia 
(as in the HKA2-null model) does not activate NCC. The mechanisms that regulate $\mathrm{NCC}$ under $\mathrm{K}^{+}$-deficiency are therefore more complicated.

Numerous studies indicate that the daily consumption of $\mathrm{K}^{+}$ in westernized populations is roughly $30 \%$ lower than that which is recommended ( $4.7 \mathrm{~g}$ or $120 \mathrm{mEq})$ by the Food and Nutrition Board of the Institute of Medicine of the National Academies (http://fnic.nal.usda.gov/dietary-guidance/drinutrient-reports/water-potassium-sodium-chloride-and-sulfate ). It is however likely that these whole "healthy" populations are not prone to hypokalemia. A recently published association study [23] showed that a slight decrease in $\mathrm{K}^{+}$excretion (reflecting a lower $\mathrm{K}^{+}$intake) raises blood pressure and that this effect is dependent on $\mathrm{Na}^{+}$excretion (also reflecting $\mathrm{Na}^{+}$ intake). In this cohort, the variations in urine $\mathrm{K}^{+}$excretion (or $\mathrm{K}^{+}$intake) was moderated (mean $2.12 \pm 0,60 \mathrm{~g} /$ day) and was not likely to be associated with a significant modifications of plasma $\left[\mathrm{K}^{+}\right]$although this parameter was not measured. The groups of people with a lower $\mathrm{K}^{+}$excretion (i.e., a lower $\mathrm{K}^{+}$ intake) were in a situation likely to correspond to our WT mice after a short period of almost complete $\mathrm{K}^{+}$restriction, i.e. in a situation where their plasma $\left[\mathrm{K}^{+}\right]$is in the normal range and their NCC is activated. This activation could explain why, in this group, as in our WT K${ }^{+}$-depleted mice, an increase in $\mathrm{Na}^{+}$ intake raises blood pressure. This comparison is however limited since we abruptly and strongly modified the diet composition of our mice and only controlled prospective studies in human with normalized low- $\mathrm{K}^{+}$and high- $\mathrm{Na}^{+}$diets intake would help confirming this hypothesis.

\section{Importance of the $\mathrm{HKA2}$ in the global response to $\mathrm{K}^{+}$ restriction}

Physiological adaptation to $\mathrm{K}^{+}$restriction requires a functional HKA2 in both the colon and kidney [12, 22]. In the present study, we showed that stimulation of HKA2 by delaying the decrease of plasma $\left[\mathrm{K}^{+}\right]$also helps at maintaining the volume of the extracellular compartment since its absence promote both hypokalemia and hypotension.

In this particular situation, since the strongest threat is the development of a non-manageable hypokalemia, in order to control the decline in plasma $\left[\mathrm{K}^{+}\right]$, the organism reduces its extracellular volume to the detriment of blood pressure. This process may be considered as a positive adaptation, as it allows the organism to concentrate $\mathrm{K}^{+}$in the extracellular compartment and therefore to maintain plasma $\left[\mathrm{K}^{+}\right]$in a bearable range.

Acknowledgments We thank Aurélie Edwards, Alain Doucet, David Mordasini and Lawrence Rabinowitz for their helpful reading of the manuscript and fruitful discussions. We are grateful to Johannes Loffing (University of Zurich) for providing the anti-NCC and anti- $\gamma \mathrm{ENaC}$ antibodies and to Nadine Bouby (Centre de Recherche des Cordeliers, Paris) for providing the V2 receptor antagonist SR 121463 A. Physiological analysis have been performed with the help of Gaelle Brideau and Nadia Frachon from the "platforme d'exploration fonctionnelle du petit animal" of the team "Métabolisme et Physiologie Rénale" at the Centre de Recherche des Cordeliers. We are grateful for the technical assistance of the CEF and of the microscopy plateform (CICC) crews. This study was supported by recurrent grants from the Institut National de la Santé et de la Recherche Médicale (INSERM) and from the Centre National de la Recherche Scientifique (CNRS).

\section{References}

1. Amlal H, Wang Z, Soleimani M (1998) Potassium depletion downregulates chloride-absorbing transporters in rat kidney. $\mathrm{J}$ Clin Invest 101:1045-1054

2. Barron WM, Stamoutsos BA, Lindheimer MD (1984) Role of volume in the regulation of vasopressin secretion during pregnancy in the rat. J Clin Invest 73:923-932

3. Castaneda-Bueno M, Cervantes-Perez LG, Rojas-Vega L, ArroyoGarza I, Vazquez N, Moreno E, Gamba G (2014) Modulation of NCC activity by low and high K+ intake: Insights into the signaling pathways involved. Am J Phys Renal Phys

4. Chabardes D, Brick-Ghannam C, Montegut M, Siaume-Perez S (1988) Effect of PGE2 and alpha-adrenergic agonists on AVPdependent cAMP levels in rabbit and rat CCT. Am J Phys 255: F43-F48

5. Cheval L, Duong Van Huyen JP, Bruneval P, Verbavatz JM, Elalouf JM, Doucet A (2004) Plasticity of mouse renal collecting duct in response to potassium depletion. Physiol Genomics 19:61-73

6. Cole JM, Khokhlova N, Sutliff RL, Adams JW, Disher KM, Zhao H, Capecchi MR, Corvol P, Bernstein KE (2003) Mice lacking endothelial ACE: normal blood pressure with elevated angiotensin II. Hypertension 41:313-321

7. Coruzzi P, Brambilla L, Brambilla V, Gualerzi M, Rossi M, Parati G, Di Rienzo M, Tadonio J, Novarini A (2001) Potassium depletion and salt sensitivity in essential hypertension. J Clin Endocrinol Metab 86:2857-2862

8. Crambert G (2014) H-K-ATPase type 2: relevance for renal physiology and beyond. Am J Phys Renal Phys 306:F693-F700

9. Crop MJ, Hoorn EJ, Lindemans J, Zietse R (2007) Hypokalaemia and subsequent hyperkalaemia in hospitalized patients. Nephrol Dial Transplant 22:3471-3477

10. Dyball RE, Powell PH (1971) The effects of substituting solutions of urea, glucose and potassium chloride for drinking water on the neurohypophysial vasopressin content of rats. J Endocrinol 49: $185-186$

11. Eaton SB, SB E III, Konner MJ (1997) Paleolithic nutrition revisited: a twelve-year retrospective on its nature and implications. Eur J Clin Nutr 51:207-216

12. Elabida B, Edwards A, Salhi A, Azroyan A, Fodstad H, Meneton P, Doucet A, Bloch-Faure M, Crambert G (2011) Chronic potassium depletion increases adrenal progesterone production that is necessary for efficient renal retention of potassium. Kidney Int 80:256262

13. Frindt G, Palmer LG (2010) Effects of dietary K on cell-surface expression of renal ion channels and transporters. Am J Phys Renal Phys 299:F890-F897

14. Geleijnse JM, Kok FJ, Grobbee DE (2004) Impact of dietary and lifestyle factors on the prevalence of hypertension in western populations. Eur J Pub Health 14:235-239

15. Grimont A, Bloch-Faure M, El Abida B, Crambert G (2009) Mapping of sex hormone receptors and their modulators along the nephron of male and female mice. FEBS Lett 583:1644-1648 
16. Guan Y, Zhang Y, Breyer RM, Fowler B, Davis L, Hebert RL, Breyer MD (1998) Prostaglandin E2 inhibits renal collecting duct $\mathrm{Na}+$ absorption by activating the EP1 receptor. J Clin Invest 102: 194-201

17. Gutsche HU, Peterson LN, Levine DZ (1984) Vivo evidence of impaired solute transport by the thick ascending limb in potassium-depleted rats. J Clin Invest 73:908-916

18. Ibrahim HN, Hostetter TH (2000) Role of dietary potassium in the hyperaldosteronism and hypertension of the remnant kidney model. J Am Soc Nephrol 11:625-631

19. Krishna GG (1990) Effect of potassium intake on blood pressure. J Am Soc Nephrol 1:43-52

20. Leviel F, Hubner CA, Houillier P, Morla L, El Moghrabi S, Brideau G, Hassan H, Parker MD, Kurth I, Kougioumtzes A, Sinning A, Pech V, Riemondy KA, Miller RL, Hummler E, Shull GE, Aronson PS, Doucet A, Wall SM, Chambrey R, Eladari D (2010) The Na + -dependent chloride-bicarbonate exchanger SLC4A8 mediates an electroneutral $\mathrm{Na}+$ reabsorption process in the renal cortical collecting ducts of mice. J Clin Invest 120:1627-1635

21. Linas SL, Marzec-Calvert R (1986) Potassium depletion ameliorates hypertension in spontaneously hypertensive rats. Hypertension 8:990-996

22. Meneton P, Schultheis PJ, Greeb J, Nieman ML, Liu LH, Clarke LL, Duffy JJ, Doetschman T, Lorenz JN, Shull GE (1998) Increased sensitivity to $\mathrm{K}+$ deprivation in colonic H,K-ATPase-deficient mice. J Clin Invest 101:536-542

23. Mente A, O'Donnell MJ, Rangarajan S, McQueen MJ, Poirier P, Wielgosz A, Morrison H, Li W, Wang X, Di C, Mony P, Devanath A, Rosengren A, Oguz A, Zatonska K, Yusufali AH, LopezJaramillo P, Avezum A, Ismail N, Lanas F, Puoane T, Diaz R, Kelishadi R, Iqbal R, Yusuf R, Chifamba J, Khatib R, Teo K, Yusuf S, Investigators P (2014) Association of urinary sodium and potassium excretion with blood pressure. N Engl J Med 371: 601-611

24. Morgan TK, Rohrwasser A, Zhao L, Hillas E, Cheng T, Ward KJ, Lalouel JM (2006) Hypervolemia of pregnancy is not maintained in mice chronically overexpressing angiotensinogen. Am J Obstet Gynecol 195:1700-1706

25. Morla L, Brideau G, Fila M, Crambert G, Cheval L, Houillier P, Ramakrishnan S, Imbert-Teboul M, Doucet A (2013) Renal proteinase-activated receptor 2 , a new actor in the control of blood pressure and plasma potassium level. J Biol Chem 288:10124 10131

26. Morris RG, Hoorn EJ, Knepper MA (2006) Hypokalemia in a mouse model of Gitelman's syndrome. Am J Phys Renal Phys 290:F1416-F1420

27. Murray BM, Paller MS (1986) Pressor resistance to vasopressin in sodium depletion, potassium depletion, and cirrhosis. Am J Phys 251:R525-R530

28. Nguyen MT, Yang LE, Fletcher NK, Lee DH, Kocinsky H, Bachmann S, Delpire E, McDonough AA (2012) Effects of K + -deficient diets with and without $\mathrm{NaCl}$ supplementation on $\mathrm{Na}+$,
$\mathrm{K}+$, and $\mathrm{H} 2 \mathrm{O}$ transporters' abundance along the nephron. Am J Phys Renal Phys 303:F92-104

29. Paice BJ, Paterson KR, Onyanga-Omara F, Donnelly T, Gray JM, Lawson DH (1986) Record linkage study of hypokalaemia in hospitalized patients. Postgrad Med J 62:187-191

30. Paltiel O, Salakhov E, Ronen I, Berg D, Israeli A (2001) Management of severe hypokalemia in hospitalized patients: a study of quality of care based on computerized databases. Arch Intern Med 161:1089-1095

31. Pedersen NB, Hofmeister MV, Rosenbaek LL, Nielsen J, Fenton RA (2010) Vasopressin induces phosphorylation of the thiazidesensitive sodium chloride cotransporter in the distal convoluted tubule. Kidney Int 78:160-169

32. Perucca J, Bichet DG, Bardoux P, Bouby N, Bankir L (2008) Sodium excretion in response to vasopressin and selective vasopressin receptor antagonists. J Am Soc Nephrol 19:1721-1731

33. Salhi A, Centeno G, Firsov D, Crambert G (2012) Circadian expression of H,K-ATPase type 2 contributes to the stability of plasma K+ levels. FASEB J 26:2859-2867

34. Salhi A, Lamouroux C, Pestov NB, Modyanov NN, Doucet A, Crambert GA (2013) Link between fertility and K+ homeostasis: role of the renal H,K-ATPase type 2. Pflugers Arch 465:1149-1158

35. Saritas T, Borschewski A, McCormick JA, Paliege A, Dathe C, Uchida S, Terker A, Himmerkus N, Bleich M, Demaretz S, Laghmani K, Delpire E, Ellison DH, Bachmann S, Mutig KSPAK (2013) Differentially mediates vasopressin effects on sodium cotransporters. J Am Soc Nephrol 24:407-418

36. Sorensen MV, Grossmann S, Roesinger M, Gresko N, Todkar AP, Barmettler G, Ziegler U, Odermatt A, Loffing-Cueni D, Loffing J (2013) Rapid dephosphorylation of the renal sodium chloride cotransporter in response to oral potassium intake in mice. Kidney Int 83:811-824

37. Terker AS, Zhang C, McCormick JA, Lazelle RA, Zhang C, Meermeier NP, Siler DA, Park HJ, Fu Y, Cohen DM, Weinstein AM, Wang WH, Yang CL, Ellison DH (2015) Potassium modulates electrolyte balance and blood pressure through effects on distal cell voltage and chloride. Cell Metab 21:39-50

38. Uyehara CF, Sarkar J (2013) Role of vasopressin in maintenance of potassium homeostasis in severe hemorrhage. Am J Phys Regul Integr Comp Phys 305:R101-R103

39. Vitzthum H, Seniuk A, Schulte LH, Muller ML, Hetz H, Ehmke H (2014) Functional coupling of renal $\mathrm{K}+$ and $\mathrm{Na}+$ handling causes high blood pressure in $\mathrm{Na}+$ replete mice. J Physiol 592:1139-1157

40. Wade JB, Liu J, Coleman RA, Grimm PR, Delpire E, Welling PA. SPAK Mediated NCC (2015) Regulation in Response to Low K+ Diet. Am J Phys Renal Phys ajprenal 0038802014

41. Wang W (2004) Regulation of renal K transport by dietary K intake. Annu Rev Physiol 66:547-569

42. Youn JH, McDonough AA (2009) Recent advances in understanding integrative control of potassium homeostasis. Annu Rev Physiol 71:381-401 